\title{
RALPH DUNCAN BROWN
}

Ralph Duncan Brown (Chief of the Missouri Basin Project, River Basin Surveys, Smithsonian Institution) died in Lincoln, Nebraska, on September 7,1952 , as the result of accidental injuries. He was born in Minneapolis, Minnesota, on March 7, 1907. After receiving his B.A. from the University of Minnesota, in 1929, Brown was a member of an expedition of the Department of Anthropology of the university, doing archaeological work in Algeria and in the Dordogne, France. The following year he was a fellow of the Laboratory of Anthropology, Santa Fe, one of a group assisting in the excavation of sites in the Whitewater District, Eastern Arizona. For several years thereafter, Brown continued archaeological work in Minnesota, particularly at the Harvey rockshelter, near Marine-on-St. Croix, which he reported briefly in the Proceedings of the Minnesota Academy of Science. He was also active at this time in the Minnesota Archaeological Society, in whose quarterly he published several notes. He spent the summer of 1935 as a member of a field party at the Kincaid mounds, then being excavated by the Department of Anthropology of the University of Chicago.

In 1936 Brown became assistant supervisor of the Minnesota Historical Records Survey, a WPA project sponsored by the Minnesota Historical Society, subsequently becoming its supervisor. A part of the work of this project was archaeological, and excavations were conducted under his direction at the site of the North West Company fur-post at Grand Portage, and at the site of Fort Ridgely, a frontier military post. At the first site Brown was personally in charge of field work. In 1938 Brown joined the WPA Archaeological Survey of Kentucky sponsored by the University of Kentucky, subsequently becoming its state supervisor.

Entering military service as a selectee in 1942, and receiving training at Fort Leonard Wood and Fort Belvoir, Brown was commissioned in 1943 in the U. S. Corps of Engineers, being assigned to the Army Map Service. Here he remained until the following year, when he was sent to combat duty. Passing through the New Guinea, Leyte, and Luzon campaigns, Brown then served in GHQ, SCAP, Tokyo. He was discharged from service with the rank of Major, in 1947, but remained for an additional period as a civilian employee of the War Department. During the last two years of his duty in Japan, and employing Japanese students at his own expense, Brown conducted two archaeological investigations. One of the sites excavated, the Ubayama shell mound, near Tokyo, has been dated by means of C-14 analysis of charcoal from structural remains from a house area in the bottom levels of the mound. Returning to the States in 1949, Brown carried on various historical and archaeological studies, and in February of 1952 joined the Missouri Basin Project.

Brown had numerous interests aside from archaeology, notably local history, particularly of Canada and the British Isles. His interest in photography was specially keen, and he spent much time, after his return from military service, at a summer cabin that he built and furnished, in Canadian waters on Rainy Lake. His zest for life and his enthusiasm were felt by all who knew him, a wide circle of friends and acquaintances who mourn his untimely death. 